UDC $81-26$

DOI: $10.17223 / 24109266 / 7 / 2$

\title{
METATEXT BASED ON CHARLES DICKENS'S NOVEL "GREAT EXPECTATIONS"
}

\author{
I.V. Gredina, A.V. Pilyukova \\ Pyatigorsk State Linguistic University (Krasnodar, Russia). \\ E-mail: L-P-Murashova@mail.ru; pravikova@mail.com
}

\begin{abstract}
The study is devoted to the brilliant adapted version of "Great Expectations" ("The Daughter of the Convict"; or, "From the Forge into Wealth") presented by the niece of L. N. Tolstoy Vera Sergeevna Tolstaya. It was she who changed the main idea of Dickens's novel bringing it closer to her own views and beliefs. Dickens's works were fascinating to V.S. Tolstaya in connection with her activity in the journal "Posrednik". She took an active part in delivering Dickens writings among peasants and those people who attended "Schools for Adults". The shortened and adapted translation simplifying the significance of Dickens's text is considered to be one of the forms of a literary interaction. An adaptation is a metatext (a secondary text) satisfying the communicative interests and the literary standards of recipients. Lexical and stylistic peculiarities of V.S. Tolstaya's metatext were distinguished; text preservation parameters were also identified. Comparative analysis or juxtapositioning of the metatext and the prototext demonstrates the key elements of V.S. Tolstaya's style: omissions of psychological observations and philosophical digressions, frequent use of simple syntactic constructions, a radical shortening of the prototext and the change of genre from novel "to novella". The aim of our study is to reveal V.S. Tolstaya's stylistic emotive meaningful dominant; the text preservation parameters; to realize idiosyncrasy of Tolstaya's style on the basis of the comparative analysis. Nevertheless, V.S. Tolstaya's position was exclusively individual and her system of omissions and additions was sometimes beyond the scope of an adaptation. She even laid claim to the coauthorship with Ch. Dickens because she did not only try to introduce the English author to Russian readers but made an attempt to bring him closer to Russian literature. This impulse reflects almost a pretention on her part to collaborate with Dickens, rather than merely translate him. As the creator of the metatext, she rendered the features of the prototext through the prism of her author's views and beliefs.

Keywords: prototext; metatext; semantic nucleus; text preservation parameters; double-voiced narrator; changing the communicative addressee of translation; Dickens's inimitable humour; refined irony; idiosyncrasy of Dickens's style.
\end{abstract}

\section{Introduction}

The problem of the hypothetical influence exerted by Dickens's later novels, particularly "Great Expectations", on Russian culture in the last four decades of the nineteenth century following their serial publication in Britain and America was our reason for investigating the nineteenth-century transla- 
tions, refashionings, and adaptations of Dickens's "Great Expectations" (1861) and their reception by Russian readers and critics. Nineteenth-century Russian translations of "Great Expectations" exhibit two main tendencies frequently considered in translation theory. The first of these tendencies is the translator's attempt to render a detailed, word-by-word representation or "literal translation" of the text so that Russian readers would completely understand fiction produced in Western Europe and America. Such a translator aimed at educating Russian readers in the literary conventions and social background of foreign works such as Dickens's novels. The first full translations of "Great Expectations" from English into Russian were originally published in serial instalments in such Russian periodicals as "Russky Bulletin" [1] anonymously, and in "Domestic Notes" [2] immediately after Dickens's novel appeared serially in "All The Year Round", his brilliantly successful magazine - it was this that gave him, in a literary form, the public platform [3: 42]. The translation done by V.A. Timiryasev, the brother of the renowned Russian scientist K.A. Timiryasev, came out in "Domestic Notes".

The version by the Russian journalist V.A. Timiryasev is considered to be the first full translation of "Great Expectations" which adequately reflects the tone and atmosphere of the original, V.A. Timiryasev being successful at both the level of stylistic equivalence and of rendering the peculiarities of Dickens's individual style [4: 125-140]. However, the authorship of the anonymous translation from "Russky Bulletin" was not established [5: 90-103].

The other tendency often exhibited by nineteenth-century Russian translators was rendering a shortened and "adapted" translation which simplified the whole meaning and significance of the original work. Such a translation may be better termed an "adaptation" or "refashioning", because it represents a reduction of a literary text to the essentials of plot and character, but fails for the most part to convey the original's digressions, descriptions, evocations of the atmosphere, and stylistic features.

At the end of the nineteenth and at the beginning of the twentieth century, Russian periodicals featured adaptations of individual chapters of "Great Expectations", their focus being on Dickens's psychological depiction of a deserted child, as for example, "The Mental Anxieties of Little Pip" [6]. This period of three decades is characterized in Russia by a gradual "lowering" of the language of classic literature so that the great works of Western European nineteenth-century literature would be accessible to children and general readers, a trend which was stimulated by the need of Russian literature to provide literary texts in the context of aesthetic tradition of educational novel, bildungsroman, or "novel of development".

Educated Russians at the end of the nineteenth century were extremely enthusiastic about becoming acquainted with the works of major Western European writers. In 1885, V.G. Chertkov, P.I. Biryukov, and the renowned 
Russian novelist Lev Nikolaevich Tolstoy undertook the editorship of "Posrednik" to enable the Russian general public to get acquainted with Western European literature. Appreciating the aesthetic and literary value of Dickens's creative heritage, L.N. Tolstoy was active in distributing and popularizing Dickens's novels, supporting the attempts of his relatives and admirers of the English writer who wished him to translate these works. Tolstoy believed that Dickens's novels were not merely entertaining, but that they could change Russian souls if made widely available in his language: "Let's take for example a novel by Walter Scott, even one by Dickens and read it to a peasant; he will understand" [7: 56]. Such a perspective may strike us as overly optimistic, but we should note that the peasant would not read the work himself; rather, the text would be delivered orally, presumably accompanied by such comments and explanations as the reader felt necessary for a relatively unsophisticated auditor. A great believer in the value of education for the peasantry, Tolstoy, inspired by Dickens's imagery, was striving to edit works of the famous English writer earlier translated into Russia in order to convey to Russian readers their moral sense.

Chertkov's "Posrednik" ("The Intermediary") is remarkable in a literary or aesthetic sense because of the work of the Count Lev Tolstoy's niece, Vera Sergeevna, who has produced fine adaptations of "Little Dorrit" and "A Christmas Carol". Her adaptation of "Little Dorrit" was entitled "Love in Prison" [8]. Her refashioning "A Christmas Carol" ("Auful Ghosts, or Resurrected Soul. A Tale") [9], composed by V.S. Tolstaya, provided Russian readers with inexpensive, highly accessible translations of Western European literature. The Countess Tolstaya created a whole series of Dickens adaptations, loving his fiction as deeply as Lev Nikolaevich did. Apparently, as a child Vera Sergeevna heard Dickens's novels being read aloud by her uncle at his estate of Yasnaja Polyana, where, "borrowing freely from Dickens, retold the stories to children in his own Tolstoyan versions" [10: 76], dramatizing each part in the manner of Dickens himself at his public readings, one of which Tolstoy attended while visiting London in 1861. The artistic merit of Dickens, his empathy for a character, for a fallen and unhappy character in particular, and the spiritual overtones of his works - all contribute to her simple but uncommonly literary presentations. According to Russian critic I. Gorbunov-Passadov, apart from Vera Sergeevna's being a very talented writer, her literary production was important because she was faithful to the ideals of her beloved uncle, Lev Nikolaevich - through whom "she became closely linked with the most genuine, most pure people's language from her childhood" [11: 143]. Not until 1896 did Tolstaya publish a full Russian language adaptation of Dickens's "Great Expectations", which appeared in "Posrednik" under the interesting title "The Daughter of the Convict"; or, "From the Forge into Wealth". A Novel. Parts 1-3. Composed after Ch. Dickens (“Дочь каторжника, или из кузницы в богатство”. Роман. 
T. 1-3. Составила по Ч. Диккенсу В.С. Толстая). The Russian title is of great interest because it reveals immediately an interpretation of the story that focuses on the situations of Estella and Pip equally.

\section{Methods}

To achieve the purpose we have to apply the following methods:

- a descriptive method to present the prototext and the metatext;

- a comparative method which is necessary to reveal common \& specific features of the original text (prototext) and metatext;

- a linguo-stylistic method of analysis in order to produce stylistic devices and emotional means;

- a component analysis method which consists in revealing text preservation parameters, whose components are text segmentation, plot, composition, the main characters.

\section{Research and Results}

One of the main themes of "Great Expectations" is the abandonment and rejection of children: Pip, the orphan who is "brought up by hand" by an older sister who grossly resents the responsibility fate has thrust upon her, has the sense as a child of always being treated as if he "had insisted on being born in opposition to the dictates of reason, religion and morality and against the dissuading arguments of his best friends. Even when he was taken to have a new suit of clothes, the tailor had orders to make them like a kind of reformatory, and on no account to let them have the free use of [his] limbs" [12: 20]. The translator's attempt to convey a strong sense of Dickens's refined humour here is important aspect of his novel in terms of the early Russian reception of "Great Expectations". The dialectics of Dickens's humour includes such categories as compassion, sympathy, and various stylistic devices that the English novelist employed in the creation of a comic imagery. In this respect, one should examine this expressive passage, noting how much Vera Tolstaya omitted in her translation.

The highly atmospheric opening scene in the graveyard which depicts Pip's encounter with Magwitch is a highly charged situation. Being held by the convict, Pip sees the world upside down, so that Dickens compels the reader to do so, too. This "inverted" perspective is a stylistic device intended to generate both humour and irony:

"The man, after looking at me for a moment, turned me upside down... When the church came to itself - for he was so sudden and strong that he made it go head over heels before me, and I saw the steeple under stone, trembling, while he ate the bread ravenously" [12:2-3].
«Я был так напуган, что у меня голова закружилась. Тогда он меня опять перевернул раза три вверх ногами и посадил на камень» [13: 9]. 
From the above juxtapositioning of the English and translated passage it is clear that Tolstaya has not even attempted to convey much of the original. In fact, she did not give the description of the church's appearing momentarily to go head-over-heels. Vera Tolstaya decreased markedly the emotional expressiveness of this excerpt by failing to reflect the atmosphere of the passage's refined irony. In fact, Tolstaya in her refashioning prevented the reader from gauging (except from Pip's actions) the individual consciousness of the boy. Instead of the dialectics of complex feelings expressed by Dickens's double-voiced narrator, in whose mind conflicting emotions hold sway, general Russian readers find only one emotion - that of sheer terror. However, a comparison of Dickens's English text and Tolstaya's Russian adaptation consistently demonstrates the Russian's unfortunate inability to convey a proper sense of Dickens's inimitable humour, as well as her omitting whole passages which flesh out Pip's double-voiced psychology, particularly his state of mind during certain key narrative moments.

It is well known that the term "translation" implies a language intermediation that aims at incorporating a "source" (foreign language) text into another language both structurally and semantically. There exist several kinds of metatext: adaptation, refashioning, stylization, digest, pastiche, parody, and so on. The authors of the article will discuss such a kind of the metatext as an adaptation. An "adaptive" translation transforms the source text into a secondary text or "metatext" in terms of language, but retains the original content. It is worth defining the notion of a metatext, the text in which specific features of literary work are used deliberately, the writer's stylistic manner is recreated; formation of metatext $\mathrm{T} 2$ on the basis of original text or prototext $\mathrm{T} 1$ takes place. At the same time the prototext's semantic nucleus or invariant passes into the metatext (See the picture below). In parallel with the invariant there exist omissions and additions which are regarded as variant elements.

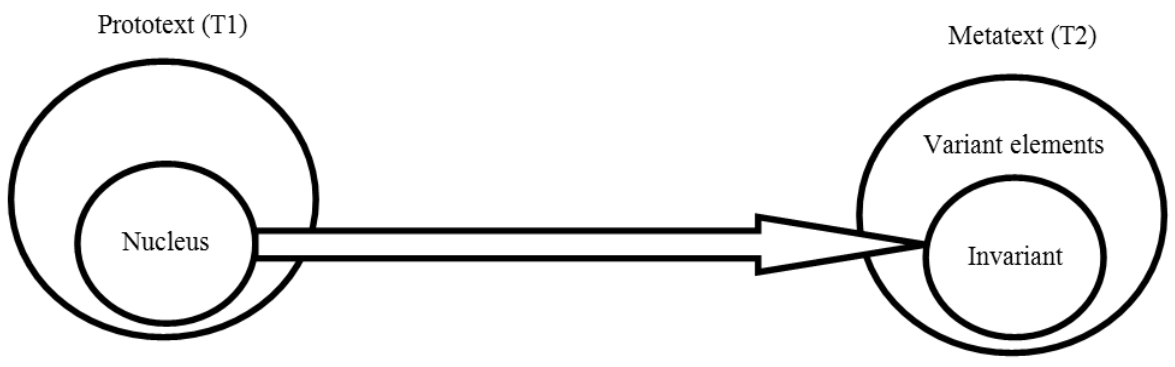

Such omissions are necessarily serious compromises to the integrity of any work of fiction, but are especially serious in a dual-first-person narrative such as "Great Expectations", which foils the naivety and incomplete understanding of the young protagonist with the worldly wisdom of the mature 
narrator. It is clear that V.S. Tolstaya rendered the Invariant (Nucleus), but created her own Variant elements. However, the purpose which she pursued was to convey the literary and socio-cultural conceptions implicit in Dickens's novel of development to as a wide a range of Russian readers as possible.

Tolstaya's restricting the reader's access to Pip's individual consciousness in the adaptation is the result of her changing the communicative addressee of this translation: whereas Dickens addressed the broad English middle class, Tolstaya appealed to the ordinary people of her vast country, the villagers, working-class, and literate peasantry.

Foregrounding the moral influence of the prospects of "great expectations" as unearned, inherited wealth upon the young man, Tolstaya underscores in her shortened translation of Dickens's text that Pip's character is deteriorating under the influence of his aristocratically-inspired delusions; further, she links his insensitivity toward Biddy here to the harmful influence of Estella upon his self-concept. However, the translator's use of low, colloquial language such as «назло» ("nazlo"), the equivalent of the verb "to spite" and «ровня» ("rovnya" - "equal") - stylistically incorrect as the equivalent for "gain her over", as well as a specific Russian historic realia or non-equivalent lexis such as «барин» ("barin" - landowner) instead of gentleman («джентльмен»), adds simplicity and naturalness to Tolstaya's translation, appropriate to the language and social environment of Russian peasants.

A comparative analysis of Tolstaya's adaptation with the original demonstrates that Dickens's psychological observations and philosophical digressions have as a rule been lost in an interpretation because, in all likelihood, she felt such material would be difficult for her Russian peasantreaders to grasp. For instance, look at the passage with the stylistic device of anaphoric repetition: "Exactly what I myself had thought... Exactly what was perfectly manifested..." - reflecting Pip's speculation about falling in love and "avoiding inconsistency", - as well as Pip's confession "but I admire her dreadfully" are omitted in her translation as subtleties beyond the comprehension of her less sophisticated readers. Although in her translation Tolstaya has shortened key passages and failed to reflect some nuances of Pip's feelings, she has, for instance, succeeded in rendering convincingly the emotional distance between Pip and Biddy imposed by Pip's newly-acquired yearnings after gentility and revulsion at all things "coarse". Though Countess Tolstaya retells rather than merely translates the original without reproducing Dickens's stylistic peculiarities, she is generally successful in interpreting both characters' feelings and emotions, so that even relatively unsophisticated Russians were able to read between the lines to comprehend such Dickens themes as the infliction of one's suffering on others, and the necessity for ultimate forgiveness and reconciliation.

Pip finds in Biddy's simple faith and home-wisdom what he has missed in Estella. But Dickens lets Pip lose Biddy without (in the original 
ending) [14: 199] gaining Estella. Martin Millhauser, considering the three endings of the last chapter of "Great Expectations", says that "Biddy might have been a modest compensation for the lost Estella in a world of reduced expectations" [15: 275]. Tolstaya remains true to Dickens's intention in not giving Pip that "compensation", although, unfamiliar as she was with the so-called "original ending" vetoed by Ellen Ternan and Bulwer-Lytton, she reproduces the poignant meeting in the garden between Pip and Estella [14: 201].

Just as in the original, so in the Russian translation the story of Pip falls into three phases which display the dialectics of his soul's evolution. In the final stage of his moral-emotional development, Pip returns to his birthplace and achieves a synthesis of the virtue of his innocent youth with the insight of his later experience. In the revised ending Pip's unrequited love is rectified, while in the original (unknown to Tolstaya), it was found in 1937 in Dickens's archive [Ibid: 199] it seems right that Estella and Pip should remain friends apart.

The key element of Tolstaya's style is her frequent use of simple syntactic constructions. In the passage just quoted, special difficulties connected with rendering Dickens's far more complex syntactic structures lie in the translation of the parallel constructions "as the morning mists had rising... so the evening mists were rising now" [12: 445] for which Tolstaya has substituted a simple Russian sentence «Месяц высоко поднимался на небе» [13: 355]; this simplification results in the Russian text's diminishing the atmosphere of the 'silver mists' associated with Pip's expectations. The nebulous tone is lost, so that Russian readers see the reunion of Pip and Estella much more distinctly (and more removed from the mists of memory) than English readers in the original text do. Apparently, the revised conclusion of the story was perceived by Russian readers as an "unhappy" ending, if we may judge from the reaction of Tolstaya's extended family. One of these family readings of Dickens's works took place on the eve of the death of the last child Vanechka. The daughter of Lev Tolstoy, Tatiana Lyvovna SukhotinaTolstaya, in her memoirs mentions that in 1895 the family gathered together to listen to the V.S. Tolstoya's translation of "Great Expectations", which had recently been completed:

On Tuesday, the 21st of February, Masha read aloud "Great Expectations", but under the title "The Daughter of the Convict", a transformation by Vera Tolstaya. When Vanechka came to say goodbye to me, I asked his opinion of the reading. He was very upset, and said: "It is so sorrowful [because] Estella did not marry Pip" [16: 389].

Despite V.S. Tolstaya's failure to realize the stylistic idiosyncrasies of Dickens's style, she has distorted the emotive-meaningful dominant of Dickens's text, her adaptation is nevertheless a genuinely creative or literary rendering of Dickens's novel in Russian an idiomatic, syntactic, and social context. 
According to the number of lexical units in her production, we have already seen how the text in the adaptation is a radical shortening of the original. Moreover, the structure of Tolstaya's adaptation differs greatly from the original in which she divided the story into three parts: the first part contains six chapters, the second part includes seven, and the third part has eleven. Consequently, her translation contains just twenty-four chapters instead of fifty-nine in the original. In Dickens's text, chapter 19 occurs at the end of the first stage of Pip's expectations, but in Tolstaya's adaptation it appears as chapter 6 , the change which reflects the much-reduced content of chapters 17, 18, and 19. Chapter 39 - the end of the second stage of Pip's expectations - corresponds to the first chapter of the third part in Tolstaya's translation. The overall shortening of Dickens's text results in some loss in terms of aesthetic reception, and may even be regarded as effecting a change of genre, that is, from novel to novella. Although Tolstaya mentions in the subtitle that hers is "A Novel in Three Parts", according to the form which she has imposed upon "Great Expectations", it becomes a mere "tale" in the Russian system of classifying works of fiction. Furthermore, the publication of Tolstaya's adaptation provoked a consideration by Russian literary critics whether such a refashioning as hers was aesthetically justified.

From 1896 through 1898 reviews of Tolstaya's translation appeared in a number of Russian journals. For instance, the anonymous author of the article "Editions for People" supposed that, "in spite of the fact that "Posrednik" has done its historic part, having opened the best writers [of Western Europe] to the general public, alterations prevented the development of good taste and distorted the reception rather than furthered a better understanding of Dickens's literary works. Commenting on the edition "The Daughter of the Convict", or "From the Forge into Wealth", the reviewer states that, "although the adaptation is good enough for the reader to demand more, Dickens's original images have grown dim, and many facts and situations of the original text have remain unclear...". Worst of all, according to the reviewer, Tolstaya has permitted her refashioning to "deviate from the main idea of the Dickens novel and tried to make the reader pay attention to advantages of a worker's life in comparison to that of a nobleman". The anonymous Russian critic concludes by stating that the book is undoubtedly interesting and well written, but that to some extent it seems to have been "pulled by the hair from the main theme of Dickens's novel" [17: 294-297].

However, the author of the review, published in "Literature for People" ("Narodnaya Literatura"), takes the opposite view. On the whole, the anonymous writer considers Tolstaya's adaptation to be very successful. According to the critic, her exposition has "preserved Dickens's language as far as possible", and even in those parts where she has to speak in her own voice the reader encounters language that is literary but simple and clear, language "without any false vulgar speech, which is a problem of adaptations". The 
reviewer defends Tolstaya, asserting that she has not violated "the plot and psychological aspect" of the Dickens novel, since she has omitted only minor, insignificant details which hamper the understanding only of unprepared readers" [18: 33]. In the reviewer's opinion, the merit of Tolstaya's adaptation will no doubt contribute to the reading public's becoming far better acquainted with the works of the famous English writer.

Pointing to Tolstaya's striving to introduce Dickens's works to the general reader of his country, Russian critic I. Gorbunov-Passadov emphasizes that Vera Sergeevna has achieved such a good rendering of the English writer's works for less educated readers that "an unenthusiastic reader, somewhere in the Russian outback, having started to read her adaptation of Dickens's "Great Expectations", couldn't tear himself away from this book" [11: 145]. These critical extracts justify our conclusions that the adaptations of Dickens's novels published in "Posrednik" (and particularly Tolstaya's) to a great extent facilitated the expansion of the English novelist's readership in Russia.

It should be emphasized that Vera Sergeevna, being faithful to the ideals of Lev Nikolaevitch Tolstoy and yet striving to live by her own standards even among "Russian gentility", deviates from the main idea of the original novel, and draws Dickens's text in translation much nearer to her own ideals. In the version by Vera Tolstaya, the main theme of the novel is determined by the antithesis between the "cult of gentleman" - one of the unshakable principles of Victorian public morality - and kindness, sincerity, and lack of prejudice exemplified in particular by two members of the lowermiddle class, Joe Gargery the blacksmith with his "awkward, speechless cordiality" and in Biddy with her "sincere belief and precise mind". It is no wonder that Vera Sergeevna, who was learning to plough, mow, and reap with her sister-countesses, in her translation emphasizes the virtues of the worker's life in the forge, and discovers Pip's worst feature as his being his snobbishness as he is suddenly transformed from a shy, uneducated village orphan into an affluent but affected London gentleman. Here she overlooked the main social thrust of the novel.

Remarkably, Vera Sergeevna refashioned the story's content by changing the title and focusing on two chief aspects of the original in her adaptation: firstly, she sought to demonstrate the moral superiority of ordinary people's lives; secondly, she emphasized the importance of Estella (who becomes almost a co-protagonist by virtue of the dualistic title) in the various plotlines by presenting her character in a highly detailed way. The title "The Daughter of the Convict", or, "From the Forge into Wealth" is two-fold in its implications: it is connected with a definite situation in the plotline, namely, that Estella is the daughter of the convict Abel Magwitch, and - generalizing the metaphorical idea in her translation - it provides a specific definition to the translator's attitudes to the nature of wealth and the dignity of manual labour. 
In her revised work the title plays an important role in Tolstaya's realization of the original's conception and the tremendous energy of the Dickens narrative; in her adaptation, she reflects the main ideas of the original. All of these features of her translation play a crucial role in shaping Russian readers' understanding of "Great Expectations", and facilitating the Russian audience's grasping something of the original's atmosphere even as it prepares them for the novel's plot development.

\section{Conclusion}

Tolstaya's position as Dickens's interpreter was extraordinarily specific; her system of 'additions' to and 'omissions' from the original is beyond the scope of an adaptation, the genre or the so called 'simple adjustments' to the peasant-reader's mentality. This impulse reflects almost a pretension on her part to collaborate with Dickens, rather than merely translate him. Recreating the narrative in the language and world view of Russian peasants and their social environment, she was eager to integrate Dickens's Christian morality within the corpus of Russian literature. This adaptation was addressed to ordinary Russian readers who were quite unfamiliar with some of the realities of the nineteenth-century English life. Under the influence of her uncle, Lev Tolstoy, who in revising previous Russian translations of Dickens those of "Our Mutual Friend" (with which he was already familiar as he had read the original in the Tauchnitz-issued serial instalments) sought to bring the language closer to that of the peasantry, believing that "one should be free in treating the original the truth of God ought be higher than the authority of a writer" [19: 324]. Vera Sergeevna treated the text of the original too freely, "Russifying" some details, as well as adding explanations and comments intended to render the novel more accessible to less sophisticated Russian readers.

In refashioning Dickens's mid-Victorian text by imposing Russian realia and associations, a process which results sometimes in a loss of the English national character, Tolstaya followed the advice of her beloved uncle in the Russian journal "Posrednik" with regard to translations of Dickens's works. Dickens's interpretations of the Christian teachings of "good" and "evil" and the literary realization of evangelical morality in his works proved to be of great value to Tolstoy, who recommended that translators exclude secondary plot lines because these would tend to hamper less sophisticated Russian readers in understanding Dickens's works, rendering complex passages of psychological revelation, for example, as incomprehensible fragments; rather, he advised translators to base their work on the experience and world view found in peasant (i.e., village and working-class) schools. Writing about the upbringing of peasants and ordinary Russian people in "Schools for Adults", Tolstoy stressed that "These are Dickens's texts by 
which one can render all the subtlety of feelings and irony, - there is no writer better than Dickens for it..." [19: 286-87]. Understanding the aesthetic and literary value of Dickens's creative heritage, V.S. Tolstoya was active in distributing and popularizing Dickens's novels in Russia.

Despite negative attitudes expressed by Russian literary scholars as they commented upon V.S. Tolstaya's techniques of translation, her full adaptation of "Great Expectations", first published in 1896, went through two re-printings, in 1898 and 1905, and is still culturally significant. Thanks to the activity of the editorship "Posrednik" and V.S. Tolstaya in particular, "Great Expectations" was widely read in Russia, and therefore, the novel had a considerable impact on educated readers in a general way, and the coming generation of Russian translators as well.

The research done has confirmed that the transition from the semantic nucleus of the prototext to the metatext and the realization of the idiosyncrasies of V.S. Tolstaya's style are revealed and taken into account.

Studying the reception of later Dickens's novels in Russia, we emphasized a special role of their adaptations and refashionings because they present a certain interest from an aesthetic point of view. They are also the issues associated with crosscultural contacts and the metatexts possessing a high potential of cultural studies. Having been created by non-professional translators they were of great ethical value. They enabled their authors to have a direct relationship to the moral education of the Russian audience. It was this that contributed to Dickens's getting into another foreign language medium, world literature and established the basis for crosscultural communication. The role of the dialogue of cultures is constantly rising and therefore, the issues associated with crosscultural interaction are assuming greater significance.

\section{References}

1. Dickens, Ch. (1861) Bol'shye Ozhidaniya. Russky Bulletin (Russky Vestnik). 31 (2). p. $778-$ 827); 32 (3). p. 221-284; 33 (5). p. 132-240; 34 (7). p. 105-144.

2. Dickens, Ch. (1861) Bol'shye Nadezhdy. In: Timiryazev V.S. (transl.). Domestic Notes (Otechestvennye Zapiski). 135-137 (4-8). 434 p.

3. Gredina, I.V. (2006) History of English Literature. Victorian Period. Tomsk: Tomsk Polytechnic University. $197 \mathrm{p}$.

4. Gredina, I.V. (2002) The Reception of Later Dickens's Novels in Russia, 1860-1880. Tomsk: Tomsk Polytechnic University. 402 p.

5. Gredina, I.V. (2001). The First Translators of Dickens's Novels "Great Expectations" and "Our Mutual Friend”. Fedorov Readings II. University Translation Studies. Philological Department of St. Petersburg State University. 2. p. 90-103.

6. Mental Anxieties of Little Pip. (1869) Collection of Texts for Reading. St. Petersburg: Konchalovsky's Edition. 103 p.

7. Lazursky, V.F. (1978) Diary. 'Note $24^{\text {th }}$ June 1824'. Tolstoy in Memoirs of His Contemporaries. Moscow: Kniga. 2. 225 p.

8. Tolstaya, V.S. (1898) Love in Prison, or, Little Dorrit. Posrednik. 234. p. 102-504. 
9. Tolstaya, V.S. (1898) Awful Ghosts, or Resurrected Soul. A Tale. Posrednik. 250. p. 107230.

10. Ivankin, I.M. (1939) Notes. 'Literaturnoe Nasledstvo'. 69. Moscow: Izdatel'stvo AS USSR. p. 21-124.

11. Gorbunov-Posadov, I. (1925) To Assist the People During Forty Years. In the Collected Papers Devoted to the Literary Activity of I. Gorbunov-Posadov. Moscow: Gos. Izdat. $445 \mathrm{p}$.

12. Dickens, Ch. (1988) Great Expectations with an Introduction by John Irving. Bantam Classic Edition. New York, Toronto, London, Sydney, Auckland: Bantam Books. 458 p.

13. Tolstaya, V.S. (1896) The Daughter of the Convict, or, From the Forge into Wealth. Moscow: Wilde, Malaya Kislovka. 1-3. 360 p.

14. Gredina, I.V. (2014) Alternative Endings of Dickens's novel "Great Expectations" in English and American Criticism. TSPU Bulletin. 5. p. 198-203.

15. Milhauser, M. (1983) 'Great Expectations': The Three Endings. Dickens Studies Annual. Southern Illinois University Press: London and Amsterdam. pp. 275-282.

16. Sukhotina-Tolstaya, T.L. (1981) Memoirs. Moscow: Iskusstvo. 428 p.

17. Editions for People (1898) Moscow: Literaturno-Polititcheskoe Izdanie. 6. 357 p.

18. Literature for People (Narodnaya Literatura) (1898) Collected Reviews of the Library Committee of the Kiev Literacy Society. Kiev. 3. 143 p.

19. Tolstoy, L.N. (1886) Letter to V.G. Chertkov (22 February, Moscow). The Complete Collection of the Works of L.N. Tolstoy. Jubilee Edition. 90 Vols. Moscow: Khudozhestvennaya Literatura. 1937. 85 (1883-1886).

\section{Information about the authors:}

Gredina Irina V., Associate professor, Department of English for Natural Science, Physics and Mathematics Faculties, Faculty of Foreign Languages, Tomsk State University (Tomsk, Russia). E-mail: Gredina@rambler.ru.

Pilyukova Antonina V., Senior Lecturer, Department of English for Natural Science, Physics and Mathematics Faculties, Faculty of Foreign Languages, Tomsk State University (Tomsk, Russia). E-mail: astro_tomsk@mail.ru. 